\title{
3D screening device for the evaluation of cell response to different electrospun microtopographies
}

Citation for published version (APA):

Criscenti, G., Vasilevich, A., Longoni, A., De Maria, C., van Blitterswijk, C. A., Truckenmuller, R., Vozzi, G., De Boer, J., \& Moroni, L. (2017). 3D screening device for the evaluation of cell response to different electrospun microtopographies. Acta Biomaterialia, 55, 310-322.

https://doi.org/10.1016/j.actbio.2017.03.049

Document status and date:

Published: 01/06/2017

DOI:

10.1016/j.actbio.2017.03.049

Document Version:

Publisher's PDF, also known as Version of record

Document license:

Taverne

Please check the document version of this publication:

- A submitted manuscript is the version of the article upon submission and before peer-review. There can be important differences between the submitted version and the official published version of record.

People interested in the research are advised to contact the author for the final version of the publication, or visit the DOI to the publisher's website.

- The final author version and the galley proof are versions of the publication after peer review.

- The final published version features the final layout of the paper including the volume, issue and page numbers.

Link to publication

\footnotetext{
General rights rights.

- You may freely distribute the URL identifying the publication in the public portal. please follow below link for the End User Agreement:

www.umlib.nl/taverne-license

Take down policy

If you believe that this document breaches copyright please contact us at:

repository@maastrichtuniversity.nl

providing details and we will investigate your claim.
}

Copyright and moral rights for the publications made accessible in the public portal are retained by the authors and/or other copyright owners and it is a condition of accessing publications that users recognise and abide by the legal requirements associated with these

- Users may download and print one copy of any publication from the public portal for the purpose of private study or research.

- You may not further distribute the material or use it for any profit-making activity or commercial gain

If the publication is distributed under the terms of Article $25 \mathrm{fa}$ of the Dutch Copyright Act, indicated by the "Taverne" license above, 
Full length article

\title{
3D screening device for the evaluation of cell response to different electrospun microtopographies
}

\author{
G. Criscenti ${ }^{\mathrm{a}, \mathrm{b}}$, A. Vasilevich ${ }^{\mathrm{a}, \mathrm{c}}$, A. Longoni ${ }^{\mathrm{a}}$, C. De Maria ${ }^{\mathrm{b}}$, C.A. van Blitterswijk ${ }^{\mathrm{a}, \mathrm{d}}$, R. Truckenmuller ${ }^{\mathrm{a}, \mathrm{d}}$, \\ G. Vozzi ${ }^{\mathrm{b}}$, J. De Boer ${ }^{\mathrm{a}, \mathrm{c}}$, L. Moroni $^{\mathrm{a}, \mathrm{d}, *}$ \\ ${ }^{a}$ Department of Tissue Regeneration, MIRA Institute for Biomedical Technology and Technical Medicine, Faculty of Science and Technology, University of Twente, Enschede, \\ The Netherlands \\ ${ }^{\mathrm{b}}$ Research Center "E. Piaggio", Faculty of Engineering, University of Pisa, Pisa, Italy \\ ${ }^{\mathrm{c}}$ Department of Cell Biology Inspired Tissue Engineering, MERLN Institute for Technology Inspired Regenerative Medicine, Maastricht University, Maastricht, The Netherlands \\ ${ }^{\mathrm{d}}$ Department of Complex Tissue Regeneration, MERLN Institute for Technology Inspired Regenerative Medicine, Maastricht University, Maastricht, The Netherlands
}

\section{A R T I C L E I N F O}

\section{Article history:}

Received 29 October 2016

Received in revised form 4 March 2017

Accepted 27 March 2017

Available online 1 April 2017

\section{Keywords:}

Electrospinning

Microtopography

Screening

Mesenchymal stromal cells

\begin{abstract}
A B S T R A C T
Micro- and nano-topographies of scaffold surfaces play a pivotal role in tissue engineering applications, influencing cell behavior such as adhesion, orientation, alignment, morphology and proliferation. In this study, a novel microfabrication method based on the combination of soft-lithography and electrospinning for the production of micro-patterned electrospun scaffolds was proposed. Subsequently, a 3D screening device for electrospun meshes with different micro-topographies was designed, fabricated and biologically validated. Results indicated that the use of defined patterns could induce specific morphological variations in human mesenchymal stem cell cytoskeletal organization, which could be related to differential activity of signaling pathways.
\end{abstract}

\section{Statement of Significance}

We introduce a novel and time saving method to fabricate 3D micropatterns with controlled microarchitectures on electrospun meshes using a custom made collector and a PDMS mold with the desired topography. A possible application of this fabrication technique is represented by a 3D screening system for patterned electrospun meshes that allows the screening of different scaffold/electrospun parameters on cell activity. In addition, what we have developed in this study could be modularly applied to existing platforms. Considering the different patterned geometries, the cell morphological data indicated a change in the cytoskeletal organization with a close correspondence to the patterns, as shown by phenoplot and boxplot analysis, and might hint at the differential activity of cell signaling. The 3D screening system proposed in this study could be used to evaluate topographies favoring cell alignment, proliferation and functional performance, and has the potential to be upscaled for high-throughput.

(ㄷ) 2017 Acta Materialia Inc. Published by Elsevier Ltd. All rights reserved.

\section{Introduction}

Surface topography influences the physico-chemical interactions at the interface between biomaterials and cells by affecting cell attachment [1-3], viability [1,4], and morphology, providing cell guidance and inducing differentiation [1,5-7]. One of the main purposes of regenerative medicine recent strategies is the fabrication of scaffolds with tailored micro/nano surface topographies to

\footnotetext{
* Corresponding author at: Department of Complex Tissue Regeneration, MERLN Institute for Technology Inspired Regenerative Medicine, Maastricht University, Maastricht, The Netherlands.

E-mail address: l.moroni@maastrichtuniversity.nl (L. Moroni).
}

stimulate biological interactions similar to those of the extracellular matrix (ECM) [7]. In order to replicate natural regenerative processes, a scaffold may mimic the composition and the structure of biological tissues to promote an adequate phenotypical response. Furthermore, scaffolds topography proved to directly influence cell adhesion, differentiation, genetic expression, migration, morphology, orientation and proliferation providing contact guidance cues and influencing the cytoskeletal arrangement $[8,9]$.

Several studies reported that structures with defined patterns promote and favour cell orientation, maturation and regulation of different cellular biological mechanisms, while randomly patterned surfaces promote non-oriented cell growth and less 
structured cellular responses [1,10,11]. Truckenmüller et al. demonstrated that the use of systems with regular and aligned channels can promote contact guidance [12], while Chew et al. assured cell elongation and alignment using solid matrices with aligned patterns [13]. Dalby et al. studied the impact of surface micro- and nano-topographies on cell behavior demonstrating that their dimensions play a pivotal role influencing cell adhesion, growth and differentiation [14,15]. A similar result was obtained by Elias et al. with the use of carbon nanofibers with diameters ranging from $60 \mathrm{~nm}$ to $200 \mathrm{~nm}$ [16]. These phenomena are probably due to differences on local surface free energy [10] or to preferential cell orientation depending on the presence of a minimal length of $2 \mu \mathrm{m}$ required for cell attachment [17].

The architecture of scaffolds used in regenerative medicine can be characterized by a macro-, micro-, and nano-structure. The macro-structure is related to the shape and dimensions of the entire scaffold, while the micro- and nano-structures refer to the scaffold surface features, which are known to act both at a cellular and sub-cellular level [7]. The macro-structure depends on the dimensions of the damaged tissue and on the implantation site, while the micro- and nano-structures are related to the structural properties of the tissue itself. When specifically looking at surface topographies of scaffolds, both micro- and nano-topographies are able to influence specific cellular responses, resulting from influencing cell morphology and adhesion [7].

Topologically, the ECM is characterized by pores, ridges and fibers of different dimensions [18]. Among the different scaffold microfabrication techniques used today to attempt mimicking such a degree of complexity, electrospinning (ESP) is a suitable alternative to fabricate random or aligned fibrous meshes to mimic the native ECM environment. Considering this possibility, researchers focused their interest on the controlled spatial arrangement of fibers to fabricate patterned structures able to mimic the micro-structure of the tissues [19]. Combining electrospinning and plasma polymerization techniques, Guex et al. developed a plasma-coated, parallel-oriented electrospun PCL scaffold that provides structurally and chemically adhesion sites for cellular attachment, thus allowing epicardial implantation and cell delivery without signs of chronic inflammations [20]. Baker et al. fabricated a dual-component (PCL-PEO) aligned nanofibrous scaffold via a dual-spinneret electrospinning setup and showed that MSCs were highly sensitive to their 3D microenvironment [21]. In particular, MSCs seeded on aligned nanofibers expressed an increase of type I collagen and a aggrecan's down-regulation and showed a highly polarized cell body with pronounced actin stress-fibers demonstrating that an aligned nanofibrous microenvironment is suitable for the production of organized fibrocartilaginous matrix [21].

Recent studies demonstrated the possibility to fabricate electrospun scaffolds with microtopographies using a custom-made collector plate [22] or combining additive manufacturing (AM) approaches with ESP $[19,23]$. Vaquette et al. investigated the use of patterned collectors to increase the pore size of electrospun scaffolds to improve cell infiltration [22]. In particular, the pattern was reproduced on the electrospun network and SEM analysis showed an increase of the pore size and pore size distribution. In addition, mechanical analysis revealed the possibility to tailor the mechanical properties according to the pattern. Rogers et al. proposed a reproducible method to design and fabricate electrospun scaffolds with defined microtopographies using a projection-microstereoli thography method to generate a patterned resin formed in a layer-by layer process [19].

However, the design of these topographies is still based on arbitrary inputs. This makes the process of identifying the optimal topography to elicit a desired cellular function still bound to a trial and error approach. The use of screening technologies could be therefore instrumental to discover optimal topographies to influence cell behavior through contact guidance. Several researchers worked on the development of 2D and 3D screening systems for different surface topographies. Lovmand et al. used a combinatorial screening approach for the fabrication of a BioSurface Structure Array two-dimensional platform for the systematic screening of cellular responses to a large variety of nano- and microstructured surfaces [24]. A tantalum array was produced on boron-doped p-type Si-wafers and a standard lithography process was used for transferring the designed arrays of patterns to the substrate. The combinations of size, gap and height of structures which enhance mineralization as well as the expression of osteogenic markers of a preosteoblastic murine cell line were identified. The same approach was used by Kolind et al. to analyse human fibroblast proliferation and mechanical response on micro-structured surfaces composed by pillars [25]. They demonstrated that altering the inter-pillar gap size of the structures caused a significant change in fibroblast proliferation and stress induced modifications in the cytoskeleton and focal adhesion morphology. We have previously developed an array of surface topographies designed using randomized algorithms to screen cell-surface topographic interactions [11]. With this technology, we demonstrated that surface topography enhanced the osteogenic differentiation of hMSCs [26,1], supported proliferation and cell-cell adhesion of induced pluripotent stem cells [26], and precisely controlled cell shape [1].

Despite these studies demonstrated the importance of surface topographies, no studies attempted to develop a method to systematically screen ESP scaffolds with different microtopographies. In this study, a novel, flexible, scalable, fast and reproducible microfabrication method based on the combination of softlithography and an ESP technique was used to produce micropatterned electrospun scaffolds. A screening device for electrospun meshes with different microtopographies that has the potential to be upscaled for high-throughput analysis was designed, fabricated and biologically validated. The system was used to screen for topographies favoring cell alignment, proliferation and functional performance. The main advantages of this approach are related to its flexibility, scalability and fast reproducibility. The system allows to design topographies based on specific inputs, to fabricate 3D micropatterned scaffolds with a large variety of personalized and controlled geometries and dimensions, which can be as well upscaled for series production.

\section{Materials and methods}

\subsection{Microfabrication technique}

The microfabrication technique used for the production of a 3D screening device is based on the combination of Soft-lithography and ESP. It consisted on the fabrication of a PDMS mold with a defined microtopography that was subsequently used as a target for the ESP jet.

\subsection{Design and fabrication of the $3 D$ screening device}

The design and fabrication of the 3D screening device was divided into three phases. Initially, a PDMS mold was fabricated from a silicon wafer with different topography geometries and sizes (Fig. 1c-d and table 1). Subsequently, the mold was positioned on top of a custom made electrode, and a polylactic co-glycolic acid (PLGA) structure was electrospun. Then, a 3D structure composed of 25 squared wells was fabricated using stereolithography in order to isolate each topography. Finally, the ESP mesh was peeled off from the PDMS mold, glued (3140 RTV Coating non-corrosive silicone rubber, Dow Corning) on a Petri dish, and the 3D structure was glued on the top of it (Fig. 1a-b). 


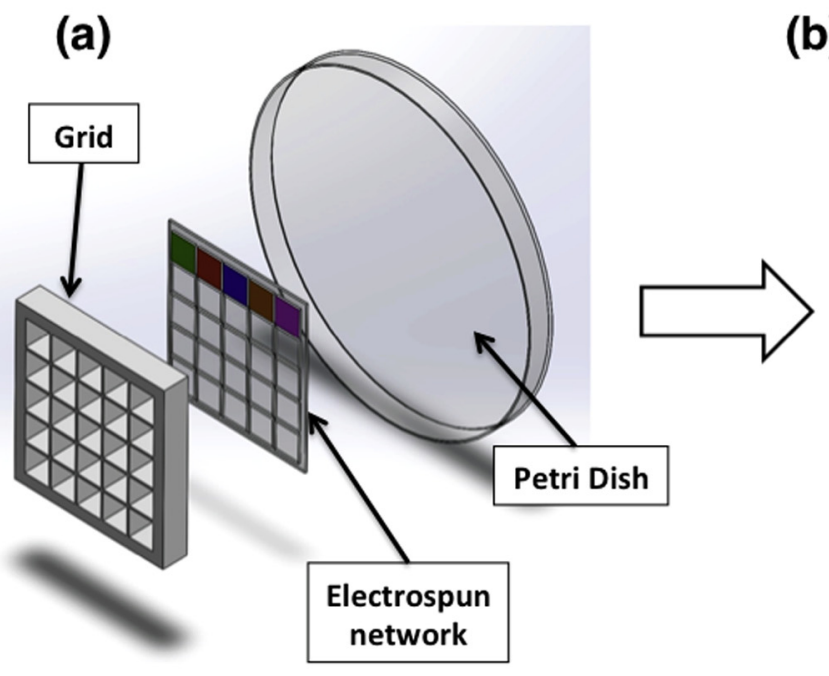

(b)

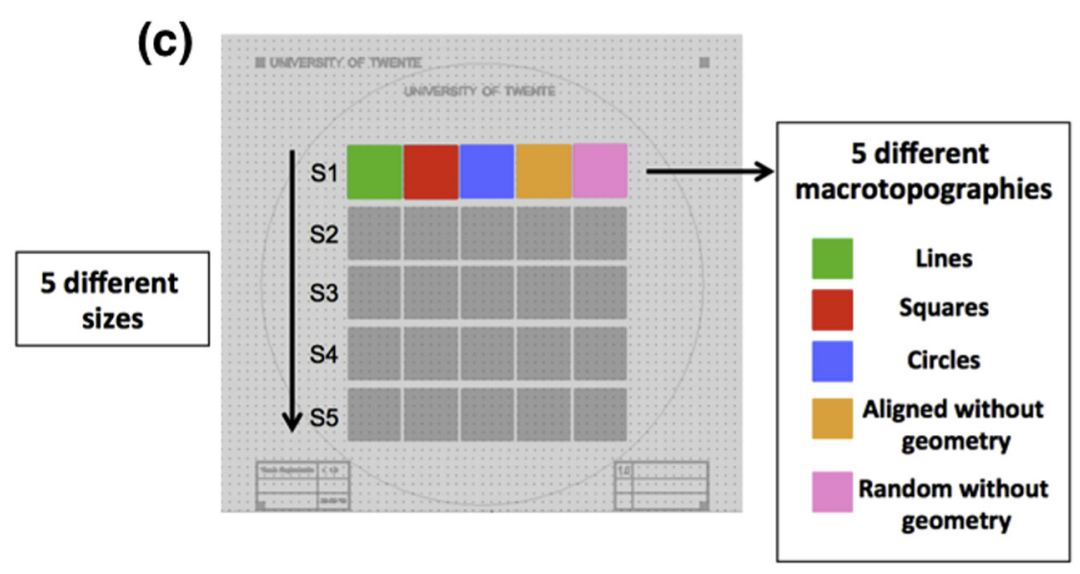

(d)

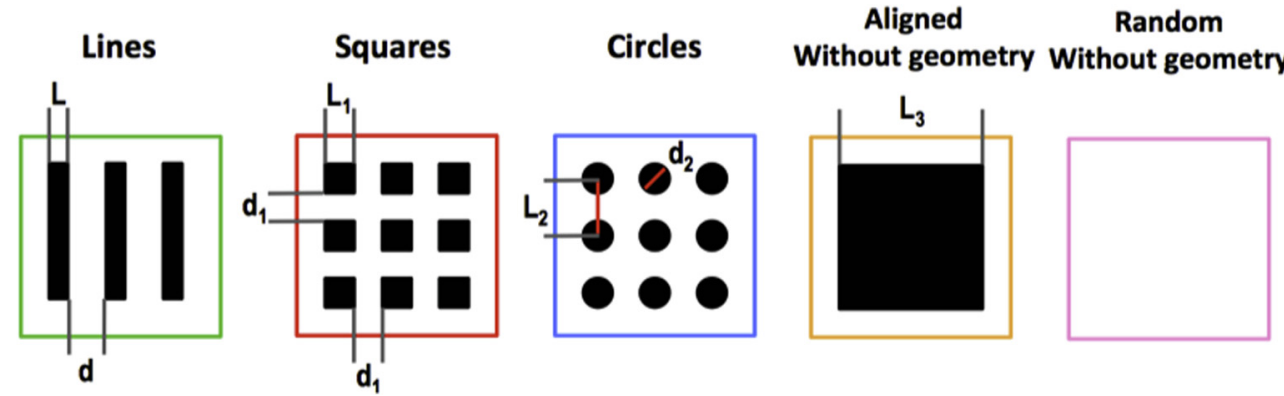

Fig. 1. (a and b) 3D screening system: it is composed by a PLGA ESP film characterized by different topographies, positioned on a Petri dish and blocked with a 3D grid fabricated via strereolithography. Initially, a PDMS mold was fabricated from a silicon wafer with different topographies and sizes. Subsequently, the mold was positioned on top of a custom made electrode, and a polylactic co-glycolic acid (PLGA) structure was electrospun. Then, a 3D structure composed of 25 squared wells was fabricated using stereolithography in order to isolate each topography. Finally, the ESP mesh was peeled off from the PDMS mold, glued on a Petri dish, and the 3D structure was glued on top of it; (c) Distribution on the silicon wafer of the different geometries and sizes used to fabricate micro-patterned electrospun scaffolds; (d) Different geometries used to fabricate micro-patterned electrospun scaffolds. The topography dimensions are specified in Table 1.

Table 1

Different sizes used for the topographical units of the micropatterned electrospun scaffolds.

\begin{tabular}{|c|c|c|c|c|c|}
\hline & Lines $(\mu \mathrm{m})$ & Squares $(\mu \mathrm{m})$ & Circles $(\mu \mathrm{m})$ & Aligned without geometry $(\mu \mathrm{m})$ & Random without geometry $(\mu \mathrm{m})$ \\
\hline S1 & $\mathrm{L}=250 \mathrm{~d}=50$ & $\begin{array}{l}\mathrm{L}_{1}=250 \\
\mathrm{~d}_{1}=50\end{array}$ & $\begin{array}{l}\mathrm{d}_{2}=250 \\
\mathrm{~L}_{2}=300\end{array}$ & $\mathrm{~L}_{3}=300$ & - \\
\hline S2 & $\mathrm{L}=200 \mathrm{~d}=50$ & $\begin{array}{l}\mathrm{L}_{1}=200 \\
\mathrm{~d}_{1}=50\end{array}$ & $\begin{array}{l}\mathrm{d}_{2}=200 \\
\mathrm{~L}_{2}=250\end{array}$ & & \\
\hline S3 & $L=150 d=50$ & $\begin{array}{l}\mathrm{L}_{1}=150 \\
\mathrm{~d}_{1}=50\end{array}$ & $\begin{array}{l}\mathrm{d}_{2}=150 \\
\mathrm{~L}_{2}=200\end{array}$ & & \\
\hline S4 & $L=100 d=50$ & $\begin{array}{l}\mathrm{L}_{1}=100 \\
\mathrm{~d}_{1}=50\end{array}$ & $\begin{array}{l}\mathrm{d}_{2}=100 \\
\mathrm{~L}_{2}=150\end{array}$ & & \\
\hline S5 & $L=50 d=50$ & $\begin{array}{l}\mathrm{L}_{1}=50 \\
\mathrm{~d}_{1}=50\end{array}$ & $\begin{array}{l}\mathrm{d}_{2}=50 \\
\mathrm{~L}_{2}=100\end{array}$ & & \\
\hline
\end{tabular}




\subsubsection{PDMS mold fabrication}

The PDMS mold was fabricated by casting on a microfabricated silicon master using the method described by Bhatia et al. [27]. Briefly, the negative photoresist $\mathrm{NANO}^{\mathrm{TM}}$ SU-8 50 (MicroChem, Newton, MA) was spin-coated on a silicon wafer, pre-baked to remove the solvent, aligned with a mask-aligner and exposed to UV rays in contact mode (NL-CLR-EV620 Mask-aligner). Subsequently, a post exposure bake to complete the polymerization of the photoresist and a development phase to remove unirradiated material were performed. The chromium mask was created using the software CleWin 4.0 and printed on a transparency using a commercial Linotronic-Hercules 3300 dpi high-resolution line printer. The mask was divided into 25 structures with different geometries (lines, squares, circles and aligned and random fibers without geometries) and size, as summarized in Fig. 1c and d and Table 1.

The PDMS mold was prepared using a commercial product (Sylgard 184 kit, Dow Corning, MI) with a 10:1 (w/w) ratio. The solution was centrifuged for $1 \mathrm{~min}$ at $300 \mathrm{rpm}$ to remove bubbles created during mixing. The mixture was casted onto a silicon wafer comprising different custom-made geometries, degassed, and finally cured in an oven for $4 \mathrm{~h}$ at $70^{\circ} \mathrm{C}$. Finally, the master was separated from PDMS and the mold was then washed with $70 \%$ ethanol (Sigma Aldrich, The Netherlands), followed by deionized MilliQ water to eliminate impurities.

\subsubsection{Electrospinning}

A random electrospun fibrous network was fabricated from a $4 \%$ $(\mathrm{w} / \mathrm{v})$ polylactic co-glycolic acid (PLGA) $85: 15$ solution in $1,1,1,3$, 3,3-hexafluoro-2-propanol (HFIP) collected directly on the PDMS mold with the different microtopographies. Random and aligned ESP fiber meshes with no microtopographies were used as control groups. The ESP parameters were equal for all the microtopographies and each control group. The voltage was $20 \mathrm{kV}$, the air gap was $20 \mathrm{~cm}$, the flow rate was $1 \mathrm{ml} / \mathrm{h}$. ESP was performed in an environmental chamber with a maintained temperature of $25^{\circ} \mathrm{C}$ and a relative humidity of $30 \%$. The polymer solution was loaded into a $5 \mathrm{ml}$ syringe (BD Biosciences) and pumped using a syringe pump (KDS-100-CE, KD Scientific) through a Teflon tube connected to a stainless steel needle $(0.5 \mathrm{~mm}$ inner diameter, $0.8 \mathrm{~mm}$ outer diameter). The needle was mounted on a $30 \times 20 \mathrm{~cm}$ upper parallel plate and centered on a custom made collector (Fig. S1). The ESP fiber density was determined as the time frame used during fabrication, which was set to $8 \mathrm{~h}$. At the end of this process, the electrospun mesh was removed from the PDMS mold and positioned on a Petri dish.

\subsubsection{Stereolithography}

In order to isolate each topography, a $5 \times 5$ custom made squared multiwell system was designed and fabricated using an EnvisionTech Perfactory MiniMultilens SLA apparatus with a pixel resolution of $16 \times 16 \mu \mathrm{m}^{2}$ and a layer thickness of $100 \mu \mathrm{m}$. This resolution can be reached for E-shell resin by using a light intensity of $140 \mathrm{~mW} / \mathrm{dm}^{2}$ and an illumination time per layer of $9 \mathrm{~s}$ (Fig. S2).

\subsection{System characterization}

\subsubsection{Geometry and architecture}

Structures morphology, geometry and architecture were characterized by scanning electron microscopy (SEM) analysis (XL 30 ESEM-FEG, Philips). Before the observations, the samples were gold sputtered (Cressington Sputter Coater 108 auto) and the fiber diameters were evaluated from SEM pictures measuring 100 fibers using FIJI image analysis software.

\subsubsection{Porosity}

The porosity was experimentally evaluated analyzing the mass and the volume of each scaffold $(\mathrm{N}=3)$, and defined as (Eq. (1)):

$P=1-\frac{\rho_{\text {struct }}}{\rho}=1-\frac{M}{V} \cdot \frac{1}{\rho}$

where $\rho$ is the specific density of the PLGA $\left(1.2825 \mathrm{~g} / \mathrm{cm}^{3}\right)$, and M and $\mathrm{V}$ are the measured mass and volume of the scaffold, respectively. The volume of the scaffold was evaluated using a $10 \mathrm{~mm} \times 15 \mathrm{~mm}$ rectangular shaped electrospun mesh, measuring the thickness with a digital micrometer (accuracy of $0.0127 \mathrm{~mm}$ and resolution of $0.001 \mathrm{~mm}$ ).

\subsubsection{Biological investigations}

Different biological investigations were performed to evaluate the effect of different electrospun microtopographies and to validate the 3D screening device.

2.3.3.1. Cell expansion. Human mesenchymal stem/stromal cells (hMSCs) (male, age 22) were purchased from the Institute of Regenerative Medicine (Temple, Texas) [28,29]. Briefly, a bone marrow aspirate was drawn and mononuclear cells were separated using density centrifugation. Cells were plated in order to obtain adherent hMSCs, which were harvested once they reached 60$80 \%$ of confluence. These cells are considered the passage zero (P0) ones. P0 hMSCs were expanded, harvested and frozen at passage 1 (P1) for distribution. Before distribution, cells were tested for MSCs CD markers by FACS and for osteogenic and adipogenic differentiation potential. P2 cells were expanded at initial seeding density of about 1000 cells $/ \mathrm{cm}^{2}$ in proliferation medium (PM). PM consists of alpha minimum essential medium (MEM- $\alpha$, Gibco) supplemented with L-glutamine (2 mM, Gibco), penicillin $(100 \mathrm{U} / \mathrm{ml}$, Gibco), streptomycin $(100 \mu \mathrm{g} / \mathrm{ml}$, Gibco), FBS (10\% w/v, Lonza), ascorbic acid (0.2 mM, Sigma) and basic fibroblast growth factor ( $1 \mathrm{ng} / \mathrm{ml}, \mathrm{bFGF}$, Instruchemie). hMSCs were harvested at approximately $80 \%$ confluency for seeding on electrospun scaffolds with different microtopographies.

2.3.3.2. Culture conditions. The grid and the electrospun film were assembled in a sterile environment. Both were sterilized in 70\% ethanol for $30 \mathrm{~min}$, subsequently washed twice in PBS for $5 \mathrm{~min}$ and finally incubated in basic medium (BM) overnight to pre-wet the electrospun scaffolds and promote protein adsorption. BM consisted of alpha minimum essential medium (MEM- $\alpha$, Gibco) supplemented with L-glutamine ( $2 \mathrm{mM}$, Gibco), penicillin $(100 \mathrm{U} / \mathrm{ml}$, Gibco), streptomycin $(100 \mu \mathrm{g} / \mathrm{ml}$, Gibco), FBS (10\% (w/v), Lonza) and ascorbic acid ( $0.2 \mathrm{mM}$, Sigma). Before the seeding procedure, the electrospun scaffolds and the entire 3D screening device were not dried. Harvested P3 hMCs were seeded on scaffolds with a density of 30,000 cells/scaffold in $1 \mathrm{ml}$ of BM. Cells were grown at $37^{\circ} \mathrm{C}$ in a humidified atmosphere with $5 \% \mathrm{CO}_{2}$.

2.3.3.3. Imaging and data analysis. A fluorescence analysis was performed to evaluate cell morphology and distribution after 3 days of culture. Briefly, scaffolds were rinsed twice with phosphatebuffered saline (PBS) solution and fixed in 10\% paraformaldehyde (PFA) for $10 \mathrm{~min}$. Cell membranes were permeabilised with $0.25 \%$ (v/v) Triton X-100 (Sigma-Aldrich) in PBS for $5 \mathrm{~min}$, and subsequently rinsed with PBS three times for $5 \mathrm{~min}$. Non specific binding was blocked using $5 \%(\mathrm{w} / \mathrm{v})$ bovine serum albumin (BSA) in PBS. Nuclei were labeled incubating the samples with $100 \mathrm{ng} / \mathrm{mL}$ of 4',6' Diamidin-2'-phenylindoldihydrochlorid in PBS (DAPI, Sigma, Munich, Germany) for $20 \mathrm{~min}$. After rinsing the sample 3 times with PBS, actin filaments were stained with $200 \mathrm{ng} / \mathrm{ml}$ of Phalloidin (Alexa Fluor 594 Phalloidin, Invitrogen) for $1 \mathrm{~h}$ to visualize 
the cytoskeleton. Sample were rinsed 3 times, mounted on a cover slip glass and stored in the dark. After the identification of individual cells, morphological measurements were performed.

Separate images for each channel were acquired by a Slide Scanner Hamamatsu Nanozoomer II and the open source software Cell Profiler (CP) was used for the image analysis [30-32]. In order to perform automated image analysis in $\mathrm{CP}$, a robust pipeline able to recognize different cell features was built and, for each individual image, intensity and illumination corrections were performed. Data analysis was performed using $\mathrm{R}$, a programming language and software environment for statistical computing and graphics [33]. Since scaffolds are characterized by a 3D structure that can introduce artifacts on image detection, a two-step $\mathrm{R}$ pipeline was build to remove them. The first step consisted of the removal of objects based on size, while the second was based on distribution of parameters for each condition.

In particular, during the first step, area ratios of cell nuclei as well as major axis ratios were determined and the objects that had ratio less than a threshold $(\mathrm{f}=1.5$ ) were removed (Fig. S3). This threshold value was chosen on the basis of visual observation to remove the majority of the outliers. In the second outlier removal step, the distribution of each single $\mathrm{CP}$ parameter for each condition was analysed and the outliers that had a value of 1.5 interquartile range below or above 1st and 3rd quantile (Tukey's method for outliers) [34] respectively, were removed (Fig. S4).

Cell shape visualization was performed using Phenoplot [35]. Before plotting, the selected features for the phenoplot representation were shown as medians per conditions and scaled from 0 to 1 . To show morphological changes, different features can be selected from literature [36-38] and at least 600 cells per condition were analysed. In this study, eight non-correlated morphological parameters were selected and detailed in Table S1 of supplementary information. In this case, all the features were scaled by subtracting the median and dividing by the median absolute deviation. Cell morphologies were compared within dimensions of different microtopographies and the cell morphology on random and aligned fibers without microtopographies were chosen as reference/control.

2.3.3.4. Cell morphology with phenoplot. Image analysis software can produce hundreds of features to describe the cell morphology, but in most cases these features are poorly interpretable. However, an alternative solution for interpretation of cell shape measurements became recently available as PhenoPlots [35]. A PhenoPlot represents image data as easily interpretable glyphs.

In order to show cell morphology differencies, a variety of univocal cell shape features such as minor/major axis, solidity and compactness were chosen (Table S1). Minor and Major axis of cells can also be combined to provide informations about cell size and eccentricity. Solidity is used to distinguish cells with protrusions or irregular shape versus generally round cells by calculating ratio between object area and convex hull area. Cells with no protrusions have solidity equals to 1 . On a phenoplot, solidity is inversely correlated to fraction and size of spikes on the plot. Compactness was calculated as the variance of the radial distance of the object's pixels from the centroid normalized by the cell area (Fig. 2b). Large cells with irregular shape have minimum compactness value. Cells with regular shape and small area have max compactness. Not intuitively, high compactness value will correspond to high variability of distances from the center of the object to its different parts. Interestingly, highly eccentric, long cells will also have high compactness values as they are far from being circle. Compactness was represented as membrane protrusion area. As an example, the phenoplots of cells with extreme cell shapes are summarized in Fig. 2a.
2.3.3.5. Presto blue assay. Presto blue assay (Life technology) was performed to evaluate cell viability, proliferation and metabolic activity after 1, 3 and 7 days of culture. Briefly, the cell permeable resazurin-based solution provided was diluted ten times in the same type of medium in which cells were cultured, according to the manufacturer's instructions. $700 \mu \mathrm{l}$ of BM supplemented with presto blue reagent were added to each plate and incubated for two hours in the dark at $37^{\circ} \mathrm{C}$ in a humidified atmosphere with $5 \% \mathrm{CO}_{2}$. The reducing power of living cells modified the reagent, which turned red in color and became highly fluorescent. From each sample, $100 \mu \mathrm{l}$ of medium were transferred in a clear bottom black 96 well plate and the colour change was detected using a spectrophotometer LS50B (Victor 3, Perkin Elmer) according to the manufacturer's instructions (excitation/emission maxima: 535-560/590-615 nm). The experiments were performed in triplicates.

2.3.3.6. DNA assay. In order to quantify the cell number, the amount of DNA was calculated with CyQuant DNA assay kit (Molecular Probes, Invitrogen), according to the manufacturer's description, after 1 and 7 days of culture. Briefly, electrospun structures were cut in order to improve the lysis efficiency. Samples were stored at $-30^{\circ} \mathrm{C}$ and freeze-thawed 5 times. Afterwards, the constructs were digested for $16 \mathrm{~h}$ at $56^{\circ} \mathrm{C}$ with $1 \mathrm{mg} / \mathrm{ml}$ proteinase $\mathrm{K}$ (Sigma Aldrich) in Tris/EDTA buffer ( $\mathrm{pH}$ 7.6). The solution is composed by $18.5 \mu \mathrm{g} / \mathrm{ml}$ of iodoacetamine (Sigma Aldrich) and $1 \mu \mathrm{g} / \mathrm{ml}$ Pepstatin A (Sigma Aldrich). To avoid the interference caused by the binding of the dye to the RNA, $100 \mu$ l of the sample were incubated for one hour at room temperature with $100 \mu \mathrm{l}$ of lysis buffer provided by the kit (Component B diluted in $180 \mathrm{mM}$ $\mathrm{NaCl}, 1 \mathrm{mM}$ EDTA in distilled water in the ratio $1: 20$ ) in which RNAse enzyme was diluted 1000 times. Quantification of the total DNA was performed using a green fluorescent dye provided by the kit (excitation $480 \mathrm{~nm}$, emission $520 \mathrm{~nm}$ ). Fluorescence was measured at $480 \mathrm{~nm}$ using a spectrophotometer LS50B (Victor 3, Perkin Elmer) and DNA concentrations were calculated from a $\lambda$ DNA standard curve.

2.3.3.7. ALP assay. Alkaline phosphatase activity after 7 days of culture was evaluated through ALP activity assay. The scaffolds were cut and stored at $-30^{\circ} \mathrm{C}$. After the thawing steps, the samples were incubated for one hour at room temperature in a cell lysis buffer composed of $0.1 \mathrm{M} \mathrm{KH}_{2} \mathrm{PO}_{4}, 0.1 \mathrm{M} \mathrm{K}_{2} \mathrm{HPO}_{4}$ and $0.1 \%$ Triton X-100 (Acros Chemicals), pH 7.8. ALP activity quantification was performed using a CDP-Star kit (Roche), according to the manufacturer's protocol. Briefly, $40 \mu \mathrm{l}$ of CDP-Star reagent were added to $10 \mu \mathrm{l}$ of cell lysate. After 15 min of incubation at room temperature in the dark, chemo-luminescence was measured at $420 \mathrm{~nm}$ with a spectrophotometer LS50B (Victor 3, Perkin Elmer). The obtained values were normalized to the DNA amount.

\subsection{Statistical analysis}

All data are expressed as mean \pm standard deviation (SD). Biochemical assays were performed with triplicate biological samples. Triplicates refer to biological statistically different samples. Each biological sample was quantified twice in technical measurements. The experiment was repeated twice. A one-way statistic analysis of variance (ANOVA) with a significant level $\mathrm{p}$ of 0.05 was used to determine differences between the groups. Tukey's multiple comparisons test was used to perform post hoc analysis. Statistical significance between the control group and the experimental groups are indicated with $\left(^{*}\right)$ which represents a p-value $<0.05,\left({ }^{* *}\right)$ which represents a p-value $<0.01$, and $\left({ }^{* * *}\right)$ which represents a $\mathrm{p}$-value $<0.001$. 


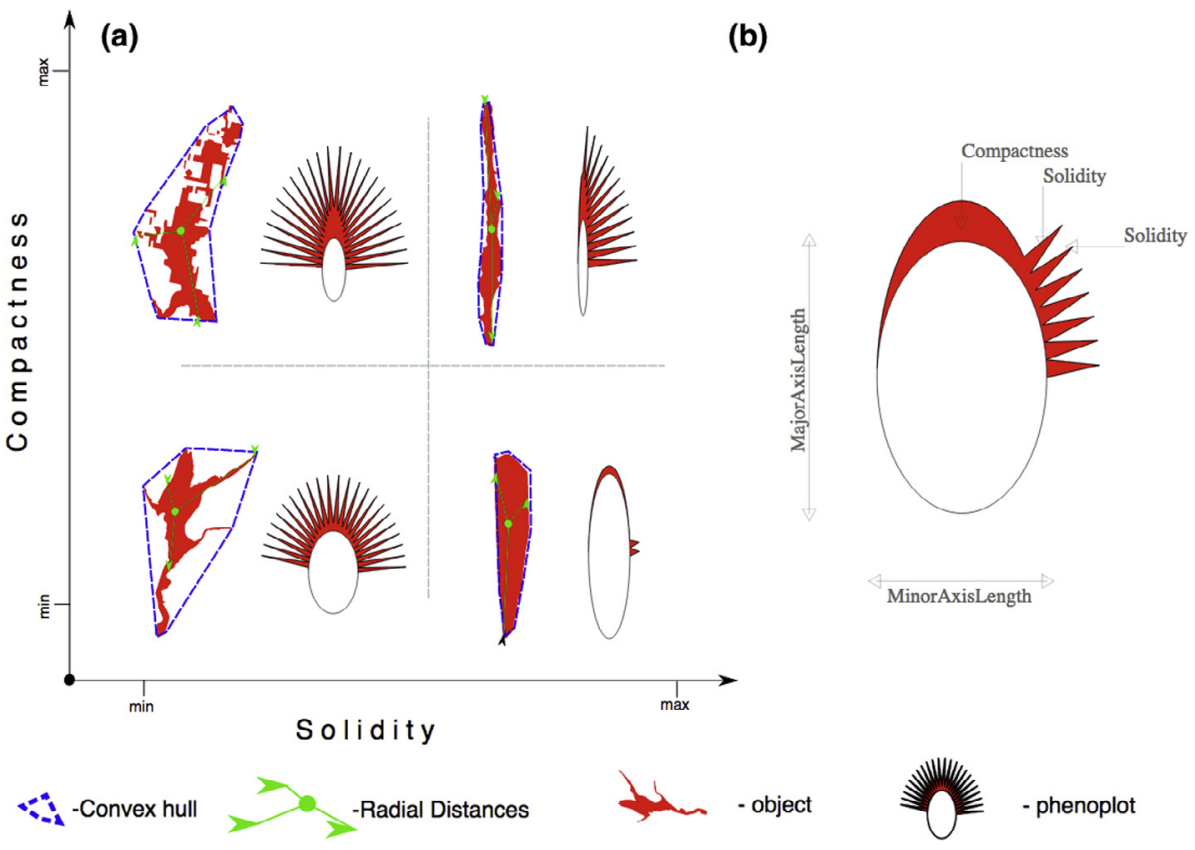

Fig. 2. Representation of cell morphologies by Phenoplot: (a) Extreme cell shapes from the screening; (b) Legend for phenoplot.

\section{Results}

\subsection{Geometry and architecture}

Electrospinning of a PLGA solution on a PDMS mold with defined microtopographies resulted in scaffolds composed of uniform nanofibers with an average diameters of $598 \pm 40 \mathrm{~nm}$, with a microstructure characterized by different patterns. The porosity of the scaffolds was $92.6 \pm 3.1 \%$. and was not affected by the different surface pattern. The produced scaffolds presented a completely interconnected porous structure and no layer delamination phenomenon occurred. The different microstructures were accurately reproduced on the electrospun network for all the different dimensions (Fig. 3).

\subsection{Representation of cell shapes by phenoplot}

Cell morphology was studied by fluorescent microscopy (Figs. 4, S6) and represented using Phenoplots (Fig. 5). Conventional boxplots can be found in supplementary informations: Figs. S5, S7S9 and show the cell size, cell eccentricity and compactness, cell extent and solidity for the different micro-topographies analysed, respectively. Briefly, considering the boxplots, no statistical differences in cell width (Minor Axis Length) on aligned and random surfaces were found. Comparing cell widths on grids with different geometries, the thinnest cells were observed on all dimensions squares except for S5. The thickest cells were observed on the lines geometry and on dimension S1 cells were thicker than the ones on random and aligned controls. Considering cell length (Major Axis Length), a high variability between dimensions for lines geometry was observed. The median radius followed the same trend of cell width. For circular pattern, cells on S2-S3 were highly eccentric; the eccentricity was similar to the one on lines S5, which was the highest. High values for compactness were detected on the same surfaces (Fig. S8). A similar trend was observed for squared patterns except for S4. For lines patterns, cells on the first four surfaces had eccentricity and compactness lower than circles and squares. However, on surface S5 there was a significant increase in both parameters. Solidity for cells on squared patterns remained the same for all the different dimensions, while values for cell extent in S3 and S4 were significantly lower (Fig. S9). For circular patterns, on surface S5 cells had the lowest solidity while extent was similar to the other dimensions. Moreover, S1 was characterized by a low value of cell extent (Fig. S9). For lines patterns, the surface S5 showed low extent and solidity and high value for compactness and eccentricity. S3 showed low level of solidity that indicates the presence of large cells with an irregular edge, while low level of extent for S2 indicated high number of philopodia (Fig. S9).

Using PhenoPlots, cell shape variations in the case of different patterns and dimensions can be clearly noticed. Considering the different patterns, cells on lines S5 showed the most distinct shape. Cells on lines S5 were highly eccentric and with a high quantity of protrusions which indicates that cells were not straight and had philopodia. These results are also confirmed by PCA analysis (Fig. S10a), where cells on surface S5 are the most distinct form the rest on a scatter plot of first 2 principal components. On clustergram (Fig. S10b), cells on lines S5 also stands apart. However, cells were not eccentric as observed for squares and circles. Cell shape on Pattern Lines S3 was similar to the one on aligned control pattern and was different from cell shape on dimensions S2 and S4. Interestingly, the smallest perturbation area was detected on dimension S1.

On squared patterns, cell shape differences within the investigated dimensions were the smallest and their protrusion area remained almost unchanged. However, on S5 cells were less eccentric and similar to random control ones. On circle patterns cell shape changes within the studied dimensions were similar to the ones present on Lines patterns. Cells on dimensions S1, S2 and S4 showed a higher compactness than cells on S3 and S5. Cell shape on dimension S3 was similar to the one on aligned control pattern and a high quantity of protrusions was detected. On circle S5 there was an increase of the protrusion area but, in contrast with lines pattern, no increase of eccentricity was detected. These findings also correlated to qualitative analysis of cell morphology by fluorescent microscopy (Figs. S5 and S6). 

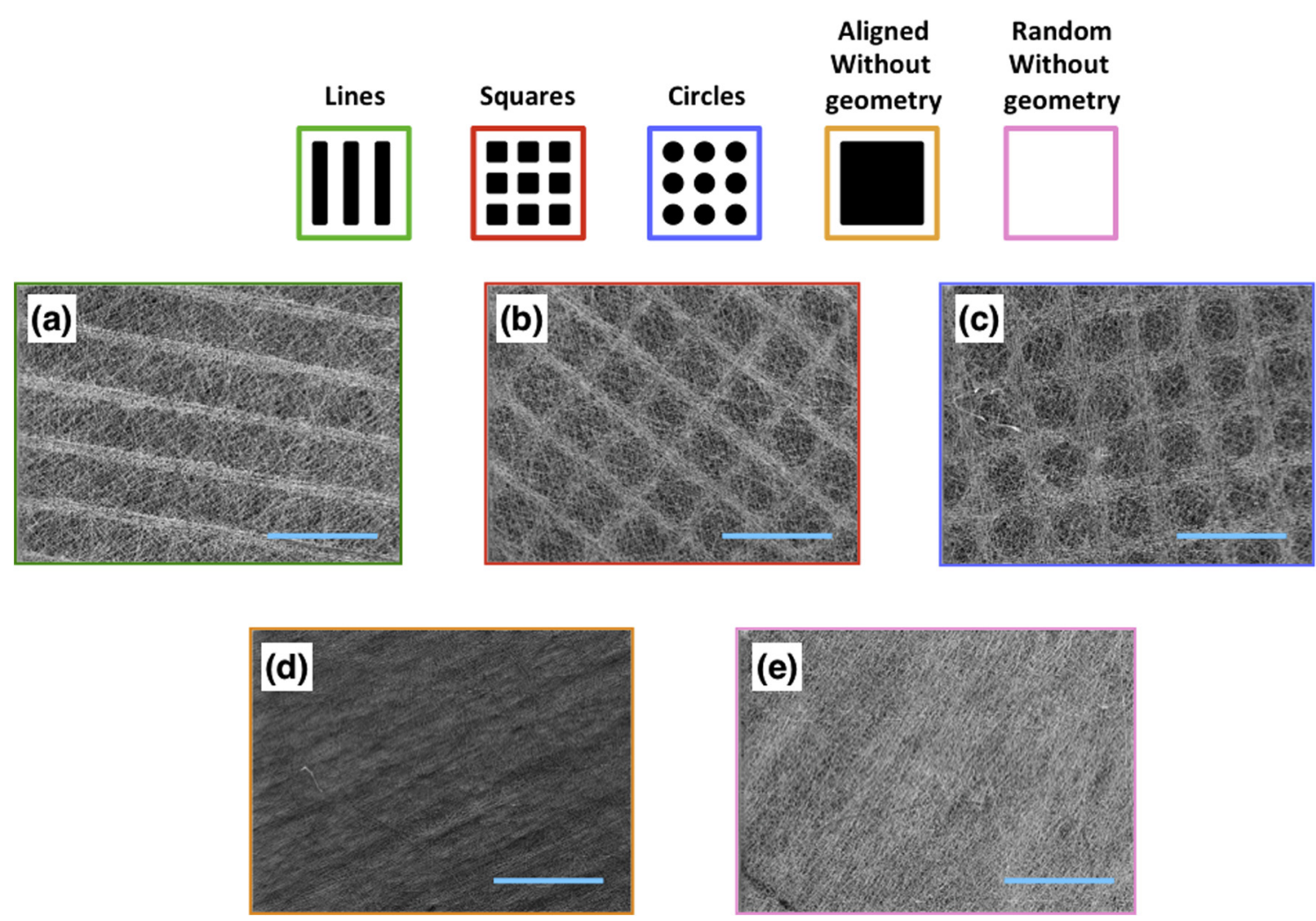

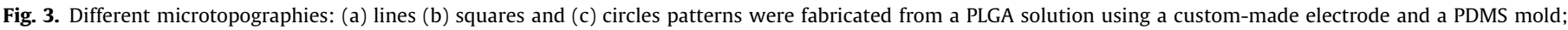
( $\mathrm{d}$ and e) aligned and random fibers without a specific topography were used as control (Scale bars: $500 \mu \mathrm{m}$ ).

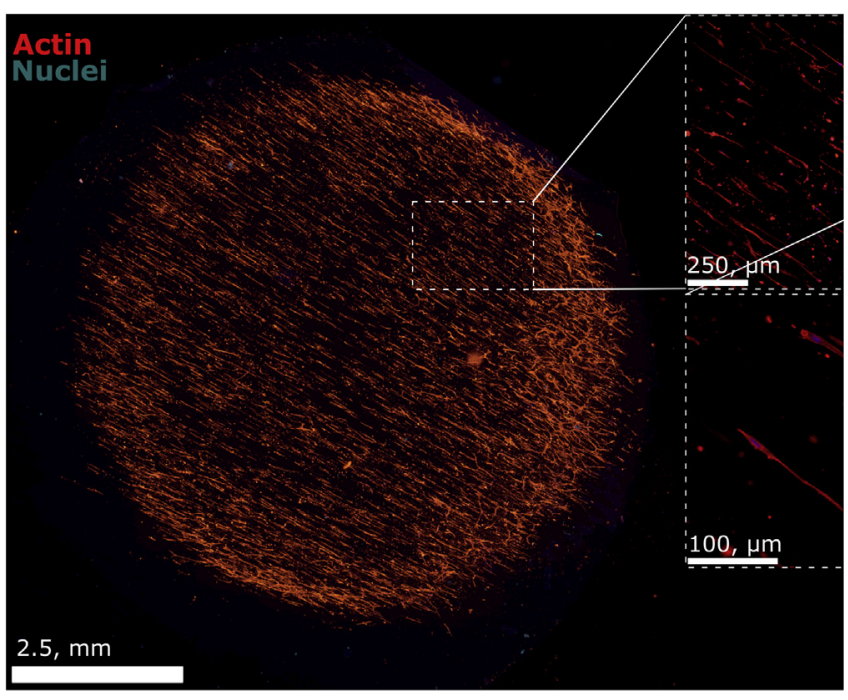

Fig. 4. Representative image of the sample used for the image analysis. Cells on patterned lines S1 are shown.

\subsection{Comparison of Orientations}

Fig. 6 shows growth directionality for each single cell in range from $-90^{\circ}$ to $+90^{\circ}$. Orientation was computed as angle between $\mathrm{X}$ axis of the image and major axis of the cell. From this plot we can see if cells were grown in random directions or they intended to grow in one direction. On control surfaces, cells grew in all possible directions, while on all patterned surfaces cells grew in a certain preferential direction. Circles S5 and squares S5 showed the worst directionality from all patterned surfaces. As previously shown, similarities of cell behavior on circular and squared patterns can be identified. Cells on patterned lines S1-S3, which didn't show high eccentricity in the previous analysis, had a lower directionality of growth compared to circular and squared patterns. Cells on circular and squared patterns (S1-S3), as well as cells on lines S4 and S5, showed the most directed pattern of growth, and the majority of cells were grown in one direction. In summary, a simple fiber alignment might be not enough to influence cell orientation, proliferation, and migration through cytoskeletal reorganization. Conversely, the cell morphological data indicated a change in the cytoskeletal organization depending on the specific microtopography patterned on the ESP meshes.

\subsection{Cell seeding efficiency, proliferation and metabolic activity}

Cell seeding efficiency (CSE) analysis was performed after $24 \mathrm{~h}$. CSE is defined as the ratio between the number of cells attached in the scaffold and the total number of seeded cells. It was evaluated considering the number of cells present in the scaffold after 1 day of culture and comparing it with the total amount of seeded cells. CSE for electrospun scaffolds was $18.7 \pm 6.2 \%$ and considering the circular pattern, no statistical differences between the different sizes were found (Fig. 7c). Observing the "lines" pattern, statistical differences were found between size S3 and the aligned network and S5 and the aligned network (Fig. 7a). Sizes S2, S4, and aligned network showed statistical differences in case of "squares" pattern (Fig. 7b).

The metabolic activity after 1, 3 and 7 days was assessed with Presto blue assay. After 1 and 3 days of culture, no statistical differences were found among the different geometries and sizes. At 7 days of culture, the surface S2 showed a significantly different decrease compared to the other sizes and the controls in the case of "lines" pattern (Fig. 7d). Circular patterns showed a statistically different increase of the metabolic activity after 7 days between S2 


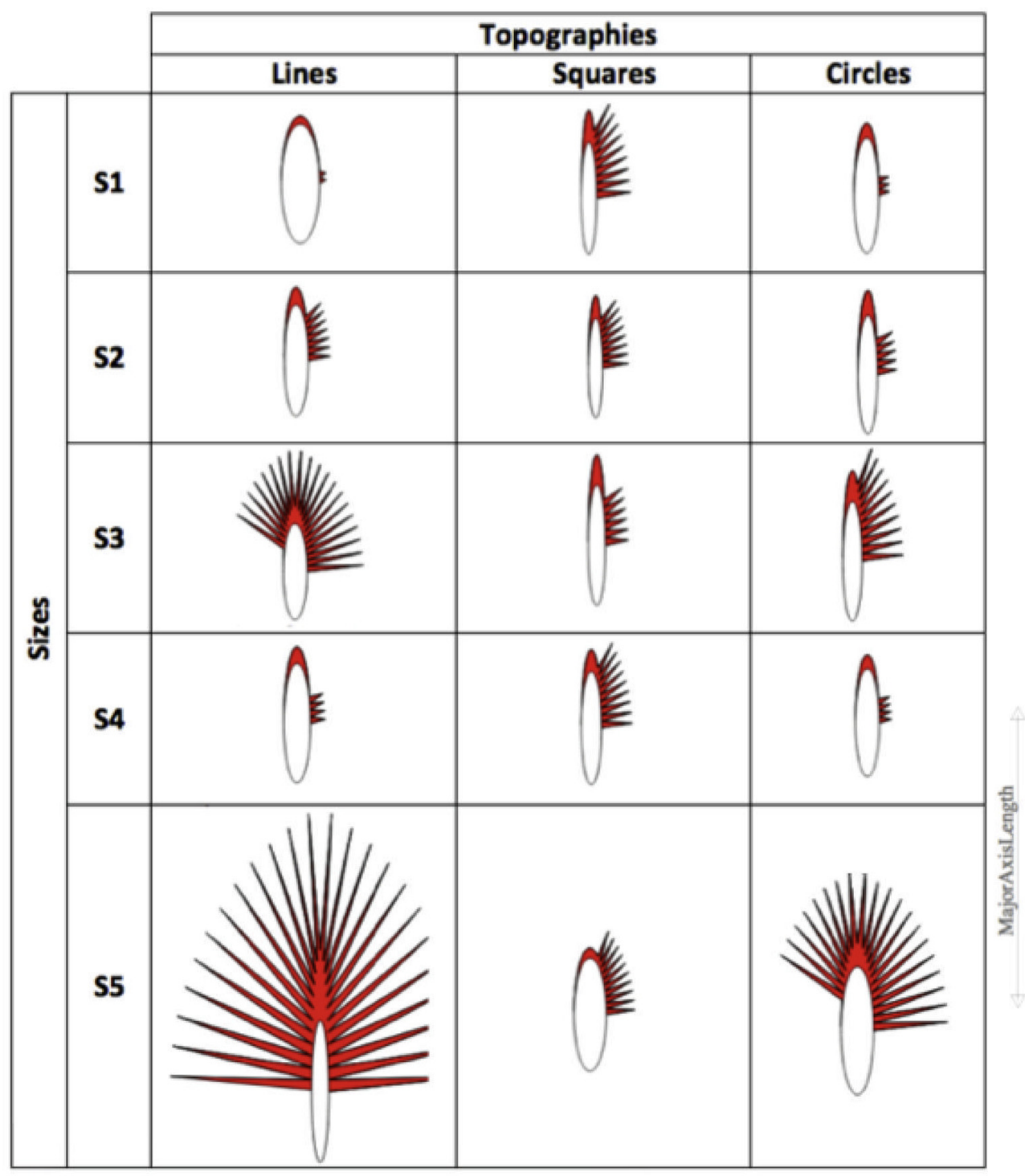

\begin{tabular}{|c|c|}
\hline \multicolumn{2}{|c|}{ Topographies } \\
\hline Aligned without geometry & Random without geometry \\
\hline
\end{tabular}

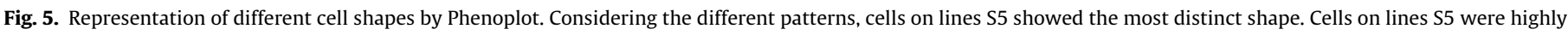

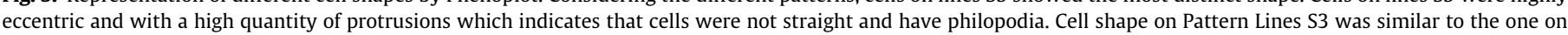

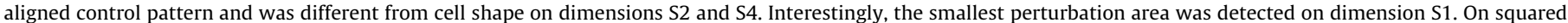

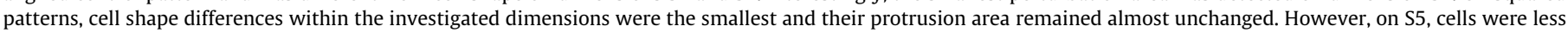

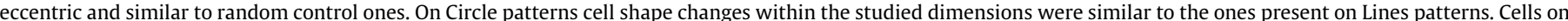

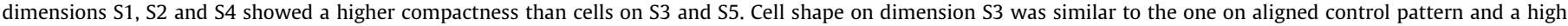

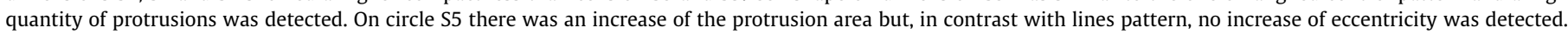

and S5, and S4 and S5 (Fig. 7f). "Square" patterns showed no difference between sizes at each time point (Fig. 7e). The DNA quantification after 7 days of cell culture showed no statistically significant differences among the different geometries and sizes (Fig. S12).

\subsection{ALP activity analysis}

Alkaline phosphatase activity after 7 days of culture in BM was evaluated through ALP activity assay. No statistically significant 


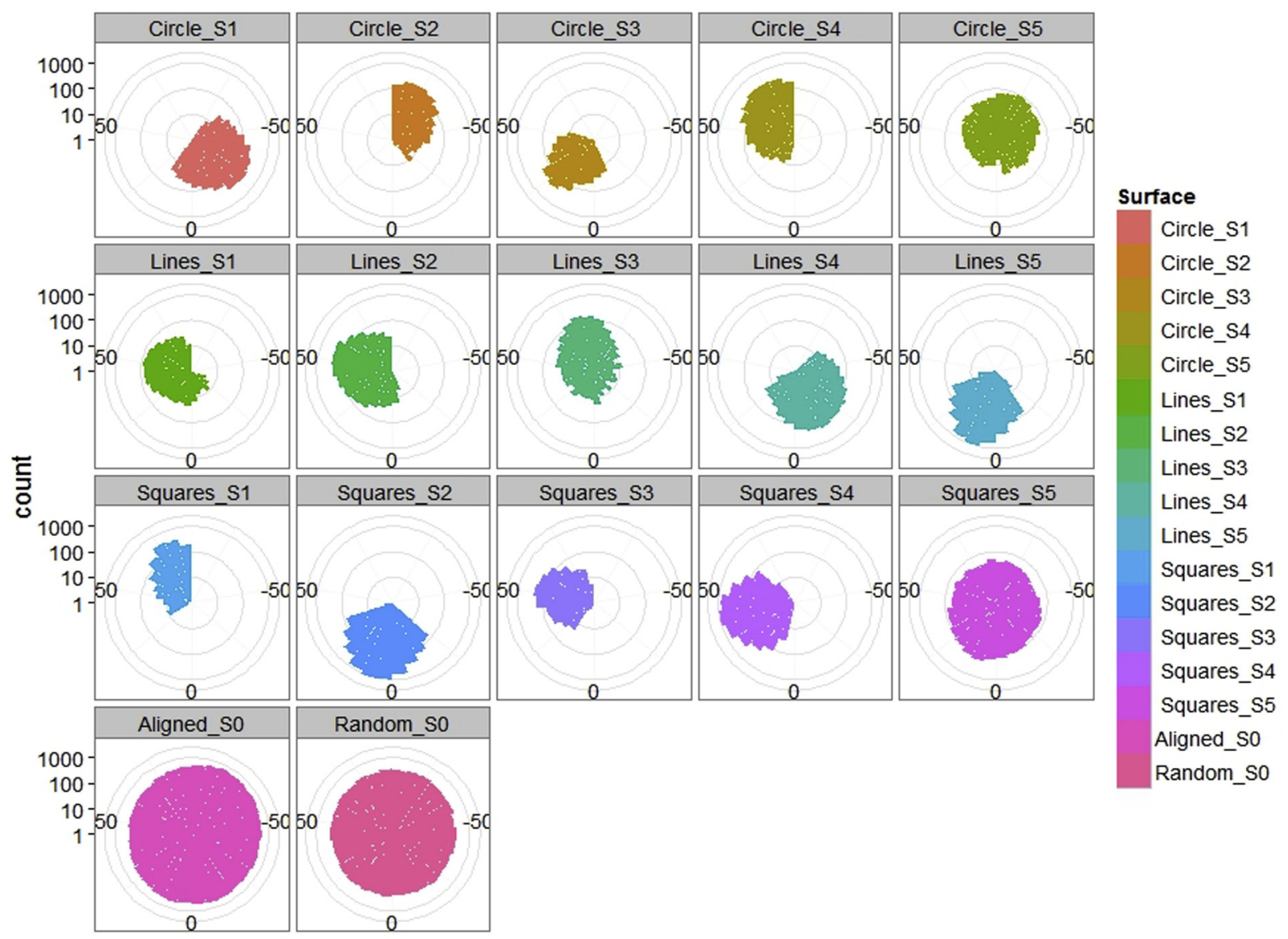

\section{Orientation}

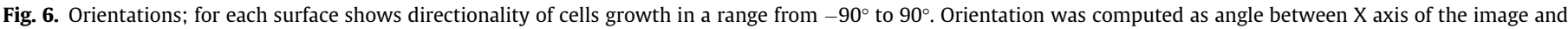

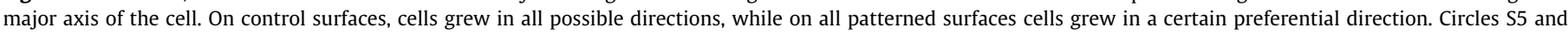

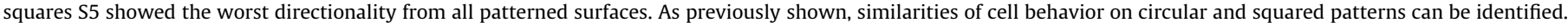

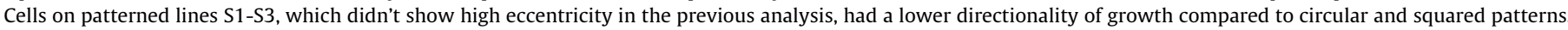

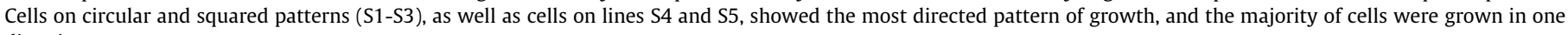
direction.

differences among the different geometries and sizes were detected (Fig. 8a-c).

\section{Discussion}

The ideal scaffold for regenerative medicine applications should mimic the topographies and the spatial structures of native tissues to promote the adequate phenotypical response [8,39]. A small change in surface topography can have a sensible effect on cell proliferation, orientation, morphology, gene expression and differentiation. In this study, a novel flexible, scalable and reproducible microfabrication method for the production of micro-patterned electrospun scaffolds based on the combination of softlithography and ESP techniques was presented. Recent studies demonstrated the possibility to fabricate electrospun scaffolds with microtopographies using custom-made patterned collector plates [22]. Neves et al. used the thread crest of a screw and a metallic net as collectors to create a pattern in ESP mesh [40], while Zhang et al. used an insulated plastic plate covered by a grounded metallic needle matrix as the collector [41]. Jia et al. fabricated electrospun nanofiber matrices using an inkjet-based system to print a solvent onto electrospun fiber meshes and selectively dissolve nanofibers to create a specific pattern [42]. However, during printing, the solvent completely dissolved the contacted fibers destroying the fibrous organization of the structure. Other research groups obtained patterned electrospun meshes combining additive manufacturing (AM) approaches with ESP [19,22]. Brown et al. combined melt ESP with an automated laterally translating collection system to create a direct writing process, which allows the fabrication of scaffolds with controllable architectures and patterns [43]. However, with this method the size of the scaffold is strongly dependent from the resolution of the translating collection system, which is limited to a few microns in feature size. Wei et al. proposed a 3D direct fabrication method based on electrohydrodynamic jet (EHD-jet) plotting of melted thermoplastic polymers on the top of a dielectric thin-plate collector with a planar motion control [44]. 3D scaffolds with regular shapes (squares and lines) were fabricated. The main limitation of this approach is related to the variety of geometries that can be obtained: only regular shapes such as squares or lines can be obtained while circular pattern are impossible to create due to limitations related to the plate-collector motion control system. Rogers et al. proposed a reproducible method to design and fabricate electrospun scaffolds with defined microtopographies using a projection-microstereolithography method to generate a patterned resin formed in a layer-by layer process [19]. Nevertheless, with this technique the minimum feature size that can be fabricated by the conventional stereolithography is limited to the beam width of the laser. In addition, it is a time-expensive process compared to the fabrication of a PDMS mold through casting on silicon wafer. 

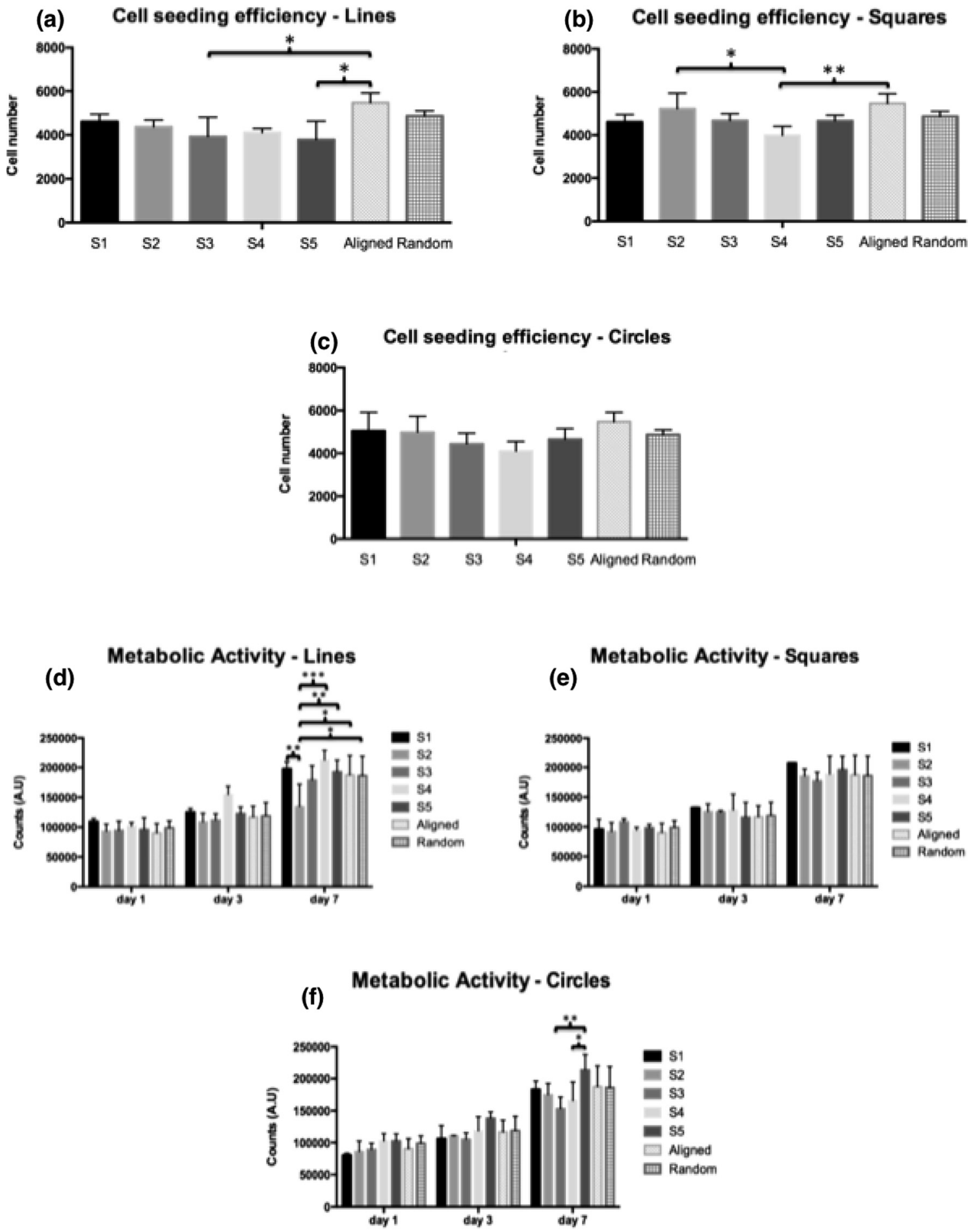

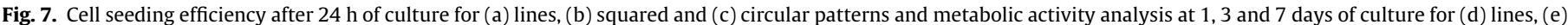

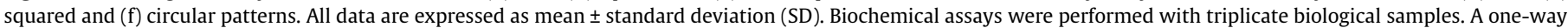

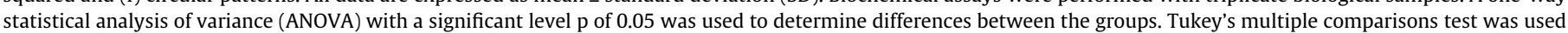

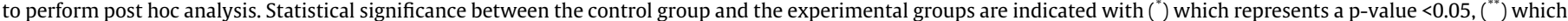
represents a $\mathrm{p}$-value $<0.01$, and $\left({ }^{* * *}\right)$ which represents a $\mathrm{p}$-value $<0.001$.

The method proposed in this study represents, therefore, a valid and fast alternative to fabricate 3D micropatterns with controlled micro-architectures using a custom made collector and a PDMS mold with the desired topography. A possible application of this fabrication method is represented by the 3D screening system for patterned electrospun meshes proposed in this study. Five different micro-topographies and sizes were fabricated to investigate
hMSCs response to different substrate microtopographies. PLGA fibers were successfully electrospun on the patterned PDMS mold and SEM analysis showed that the electrospun scaffolds mirrored the geometries and the dimensions demonstrating the versatility of this approach. Similar results were obtained by Rogers et al. [19]. Other works from our laboratories revealed the possibility to fabricate similar patterned electrospun scaffolds using PLLA, 

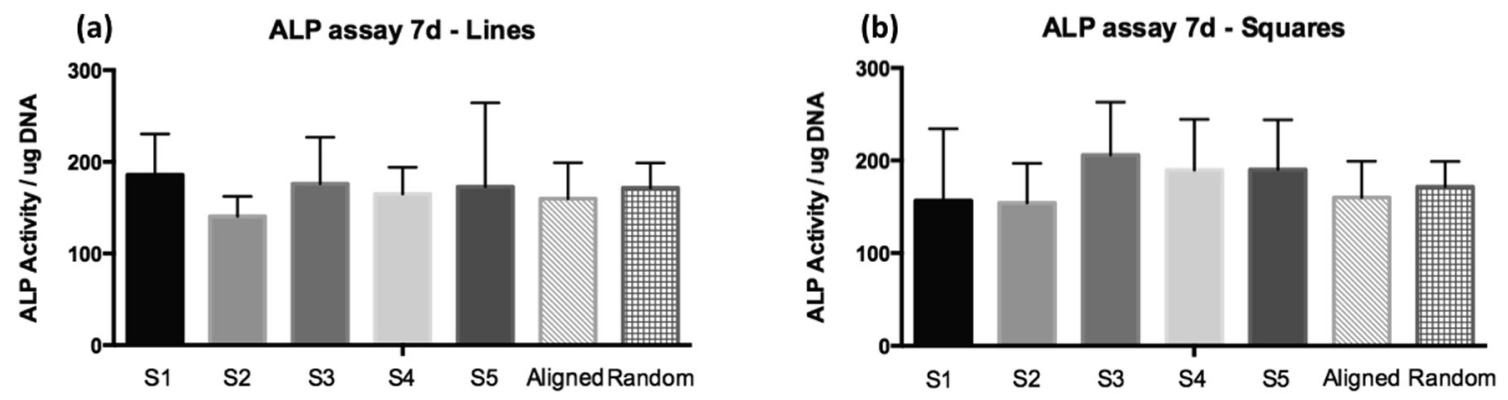

(c)

ALP assay $7 d$ - Circles

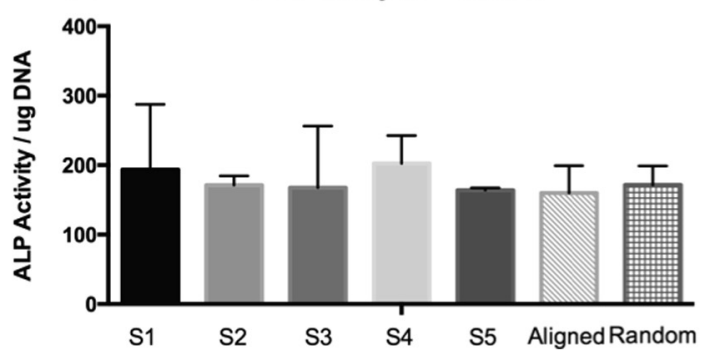

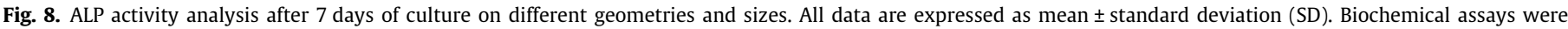

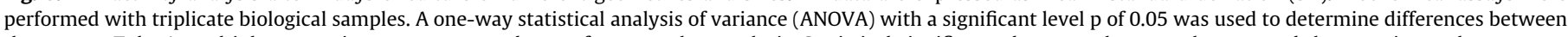

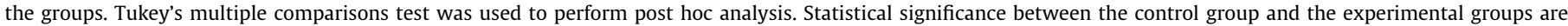
indicated with $\left(^{*}\right)$ which represents a p-value $<0.05,\left({ }^{* *}\right)$ which represents a p-value $<0.01$, and $\left({ }^{* * *}\right)$ which represents a p-value $<0.001$.

PEOT/PBT and PCL, demonstrating the flexibility and transferability of this method to other biomaterials (data not shown).

The ESP networks with the different geometries here presented closely mimic the fibrous nature of the ECM [45-47]. In order to investigate the cell response to the fabricated patterned surfaces, their morphology and distribution were analysed through image analysis. The effect of fiber orientation was showed comparing random and aligned fibers without microgeometries. As expected, cells on aligned scaffolds were more elongated then the ones on random fibers. At the same time, cells on random fibers were larger with irregular shape. In general, cells on random fibers had more extensions, while cells on aligned fibers had a higher body length. This result confirmed the importance of a regular alignment of fibers for the guidance of cellular behavior. However, the cell morphology showed on the aligned structures demonstrated that a simple fiber alignment might be not enough to influence cell behavior and promote their growth, migration and orientation influencing the cytoskeleton arrangement.

Considering the different patterned geometries, the cell morphological data indicated a change in the cytoskeletal organization, as shown by phenoplot and boxplot analysis, and might hint at the differential activity of signaling pathways. However, visualization of cell shape data is always a challenge: on one hand it should be a good representation of biological variation; on the other hand it should be easily interpretable by non statistician which is not always possible with highly dimensional data. Phenoplot is able to capture multidimensional data from the single cell data and display information in glyphs that are immediately recognized by biologists [35]. Observing the lines pattern, hMSCs showed the tendency to increase their length, modify their shape and start to change their orientation following the defined pattern.

Similar results were found in literature where topographical patterns have been used to control cellular morphology including cell shape and cytoskeletal organization [48-50]. In the last two decades, different microtopographies with different sizes were used to evaluate the response of different cell types demonstrating that the surface topography directly affects cell morphology, alignment and motility, cytoskeletal arrangement, proliferation and gene expression $[18,21,48,51]$.
Preliminary biological investigations showed an increase of the metabolic activity within culturing time, indicating that the cells were alive and proliferating. However, no significant differences in DNA content and ALP activity were observed. This may be due to the early time points used for the analysis, as it is known that MSCs differentiation on 3D scaffolds is typically delayed compared to conventional 2D culture plates [52]. Furthermore, osteogenic culture medium could be used to assess the influence of the different geometrical cues superimposed on the electrospun meshes. Yet, in this study we aimed at evaluating the effect of the geometrical cues excluding the effect of specific culture media.

To the best of our knowledge, there is no platform available in commerce that would allow the screening of different scaffold/electrospun parameters on cell activity and the 3D screening system proposed in this study is the first that presents different surface topographies for the evaluation of cells response to contact guidance. On the other side, what we have developed in this study could be modularly applied to existing platforms. The idea of multiwell platforms with electrospun meshes was already proposed and a commercial product, the MIMETIX tissue culture plates with random or aligned ESP fibers, is already available. This solution is available with different fiber diameters, pore sizes and scaffold thicknesses. However, there is no possibility to tailor the surface topography to promote a specific cell response.

The main difficulties of the presented method are related to the design of the custom made collector and to the assembling procedure. In the first case, a specific collector geometry was designed to adequately focus the ESP jet on top of the dielectric PDMS mold, while in the second one a specific design of the multiwells system and glue were used to prevent leakage and avoid connections between the different wells. Considering the geometries and architecture analysis, the main difficulty is related to the measurement of the height of the different features. Despite different analysis such as AFM and SEM were performed, it was not possible to evaluate the height because the structure folds on itself making the measurement unreliable. In addition, glyph-like cells visualization methods, such as PhenoPlot, are a powerful approach that help to visualize cells through image analysis measurements and make biological sense from them. However, they provide informations 
about the average cell without showing the variability of the parameters. For these reasons, they cannot fully replace traditional statistical data visualization approaches such as bars and boxplots. Thus, Phenoplots can be utilized as additional data visualization tool that help to interpret the data.

Future investigations should focus on the optimization of the assembling procedure of the screening system and on the upscale for high-throughput analysis. The implementation of new geometries, sizes and biomaterials will be fundamental to achieve this objective. In addition, mechanical analysis of the patterned scaffolds could be performed to evaluate the effect of the various patterns on the overall scaffolds' mechanical properties. The possibility to add bioactive agents on the fiber composition represents another future development for this system. Further biological investigations such as gene expression analysis should be performed to investigate cell differentiation at different time points.

\section{Conclusions}

In conclusion, the 3D screening device for electrospun meshes with different microtopographies seems to induce different cell organization with a close correspondence to the patterns. 3D screening could be used to evaluate topographies favoring cell alignment, proliferation and functional performance and it has the potential to be upscaled for high-throughput.

\section{Acknowledgements}

We would like to acknowledge STW (grant number 11135) for funding and Martijn Tibbe for its precious support for the fabrication process. The research leading to these results has received funding from the European Union's Seventh Framework Programme (FP7/2007-2013) under grant agreement no 289720. This project/research has been made possible with the support of the Dutch Province of Limburg.

\section{Appendix A. Supplementary data}

Supplementary data associated with this article can be found, in the online version, at http://dx.doi.org/10.1016/j.actbio.2017.03. 049.

\section{References}

[1] M. Hulsman, F. Hulshof, H. Unadkat, B.J. Papenburg, D.F. Stamatialis, R. Truckenmüller, C. van Blitterswijk, J. de Boer, M.J.T. Reinders, Analysis of highthroughput screening reveals the effect of surface topographies on cellular morphology, Acta Biomater. 15 (2015) 29-38.

[2] Z. Pan, Z. Qu, Z. Zhang, R. Peng, C. Yan, J. Ding, Particle-collision and porogenleaching technique to fabricate polymeric porous scaffolds with microscale roughness of interior surfaces Chinese, J. Polym. Sci. 31 (2013) 737-747.

[3] Y.L. Khung, G. Barritt, N.H. Voelcker, Using continuous porous silicon gradients to study the influence of surface topography on the behaviour of neuroblastoma cells, Exp. Cell Res. 314 (2008) 789-800.

[4] Z. Qu, J. Ding, Physical modification of the interior surfaces of PLGA porous scaffolds using sugar fibers as template, J. Biomater. Sci. Polym. Ed. 24 (2013) 447-459.

[5] P.-Y. Wang, L.R. Clements, H. Thissen, A. Jane, W.-B. Tsai, N.H. Voelcker, Screening mesenchymal stem cell attachment and differentiation on porous silicon gradients, Adv. Funct. Mater. 22 (2012) 3414-3423.

[6] O.F. Zouani, C. Chanseau, B. Brouillaud, R. Bareille, F. Deliane, M.-P. Foulc, A Mehdi, M.-C. Durrieu, Altered nanofeature size dictates stem cell differentiation, J. Cell Sci. 125 (2012) 1217-1224.

[7] X. Le, G.E.J. Poinern, N. Ali, C.M. Berry, D. Fawcett, Engineering a Biocompatible Scaffold with Either Micrometre or Nanometre Scale Surface Topography for Promoting Protein Adsorption and Cellular Response, Int. J. Biomater. (2013) Article ID 782549

[8] S. Oh, K.S. Brammer, Y.S.J. Li, D. Teng, A.J. Engler, S. Chien, et al., Stem cell fate dictated solely by altered nanotube dimension, Proc. Natl. Acad. Sci. U. S. A. 106 (2009) 2130-2135.
[9] S.C. Neves, C. Mota, A. Longoni, C.C. Barrias, P.L. Granja, L. Moroni, Additive manufactured polymeric 3D scaffolds with tailored surface topography influence mesenchymal stromal cells activity, Biofabrication 8 (2016) 025012.

[10] C.A.M. Portugal, R. Truckenmüller, D. Stamatialis, J.G. Crespo, Effect of tissue scaffold topography on protein structure monitored by fluorescence spectroscopy, J. Biotechnol. 189 (2014) 166-174.

[11] H.V. Unadkat, M. Hulsman, K. Cornelissen, B.J. Papenburg, R.K. Truckenmüller, A.E. Carpenter, M. Wessling, G.F. Post, M. Uetz, M.J.T. Reinders, D. Stamatialis, C.A. van Blitterswijk, J. de Boer, An algorithm-based topographical biomaterials library to instruct cell fate, PNAS 108 (40) (2011) 1656516570, http://dx.doi.org/10.1073/pnas.1109861108.

[12] R. Truckenmüller, S. Giselbrecht, M. Escalante-Marun, M. Groenendijk, B. Papenburg, N. Rivron, H. Unadkat, V. Saile, V. Subramaniam, A. van den Berg, C. van Blitterswijk, M. Wessling, J. de Boer, D. Stamatialis, Fabrication of cell container arrays with overlaid surface topographies, Biomed. Microdevices 14 (2012) 95-107.

[13] S.Y. Chew, R. Mi, A. Hoke, K.W. Leong, The effect of the alignment of electrospun fibrous scaffolds on Schwann cell maturation, Biomaterials 29 (2008) 653-661.

[14] M.J. Dalby, M.O. Riehle, H.J.H. Johnstone, S. Affrossman, A.S.G. Curtis, Polymerdemixed nanotopography: control of fibroblast spreading and proliferation, Tissue Eng. 8 (2002) 1099-1108.

[15] M.J. Dalby, M.O. Riehle, H.J.H. Johnstone, S. Affrossman, A.S.G. Curtis, Nonadhesive nanotopography: fibroblast response to poly(n-butyl methacrylate)-poly(styrene) demixed surface features, J. Biomed. Mater. Res. A 67 (2003) 1025-1032.

[16] K.L. Elias, R.L. Price, T.J. Webster, Enhanced functions of osteoblasts on nanometer diameter carbon fibers, Biomaterials 23 (2002) 3279-3287.

[17] C.S. Izzard, L.R. Lochner, Cell to substrate contacts in living fibroblasts. An interference reflexion study with an evaluation of the technique, J. Cell Sci. 21 (1976) 129-159.

[18] R.G. Flemming, C.J. Murphy, G.A. Abrams, S.L. Goodman, P.F. Nealey, Effects of synthetic micro- and nano-structured surfaces on cell behavior, Biomaterials 20 (1999) 573-588.

[19] C.M. Rogers, G.E. Morris, T.W.A. Gould, R. Bail, S. Toumpaniari, H. Harrington, J. E. Dixon, K.M. Shakesheff, J. Segal, F.R.A.J. Rose, A novel technique for the production of electrospun scaffolds with tailored three-dimensional micro-patterns employing additive manufacturing, Biofabrication 6 (2014) 035003.

[20] A.G. Guex, A. Frobert, J. Valentin, G. Fortunato, D. Hegemann, S. Cook, T.P. Carrel, H.T. Tevaearai, M.N. Giraud, Plasma-functionalized electrospun matrix for biograft development and cardiac function stabilization, Acta Biomater. 10 (2014) 2996-3006.

[21] B.M. Baker, A.S. Nathan, A.O. Gee, R.L. Mauck, The influence of an aligned nanofibrous topography on human mesenchymal stem cell fibrochondrogenesis, Biomaterials 31 (2010) 6190-6200.

[22] C. Vaquette, J.J. Cooper-White, Increasing electrospun scaffold pore size with tailored collectors for improved cell penetration, Acta Biomater. 7 (2011) 2544-2557.

[23] P.D. Dalton, C. Vaquette, B.L. Farrugia, T.R. Dargaville, T.D. Brown, D.W Hutmacher, Electrospinning and additive manufacturing: converging technologies, Biomater. Sci. 1 (2013) 171.

[24] J. Lovmand, J. Justesen, M. Foss, R.H. Lauridsen, M. Lovmand, C. Modin, F. Besenbacher, F.S. Pedersen, M. Duch, The use of combinatorial topographical libraries for the screening of enhanced osteogenic expression and mineralization, Biomaterials 30 (2009) 2015-2022.

[25] K. Kolind, A. Dolatshahi-Pirouz, J. Lovmand, F.S. Pedersen, M. Foss, F. Besenbacher, A combinatorial screening of human fibroblast responses on micro-structured surfaces, Biomaterials 31 (2010) 9182-9191.

[26] A. Reimer, A. Vasilevich, F. Hulshof, P. Viswanathan, C.A. van Blitterswijk, J. de Boer, F.M. Watt, Scalable topographies to support proliferation and Oct4 expression by human induced pluripotent stem cells, Sci. Rep. 6 (2016) 18948.

[27] S.N. Bhatia, C. Chen, Tissue engineering at the micro-scale, Biomed. Microdevices 2 (2) (1999) 131-144.

[28] C.M. Di Girolamo, D. Stokes, D. Colter, D.G. Phinney, R. Class, D.J. Prockop, Propagation and senescence of human marrow stromal cells in culture: a simple colony-forming assay identifies samples with the greatest potential to propagate and differentiate, Br. J. Haematol. 107 (1999) 275-281.

[29] M. Dominici, K. Le Blanc, I. Mueller, I. Slaper-Cortenbach, F. Marini, D.S. Krause, R.J. Deans, A. Keating, D.J. Prockop, E.M. Horwitz, Minimal criteria for defining multipotent mesenchymal stromal cells. The International Society for Cellular Therapy position statement, Cytotherapy 8 (2006) 315-317.

[30] A.E. Carpenter, T.R. Jones, M.R. Lamprecht, C. Clarke, I.H. Kang, O. Friman, D.A. Guertin, J.H. Chang, R.A. Lindquist, J. Moffat, P. Golland, D.M. Sabatini, Cell Profiler: image analysis software for identifying and quantifying cell phenotypes, Genome Biol. 7 (2006) R100.

[31] http://www.cellprofiler.org/citations.shtml.

[32] J.M. Chambers, W.S. Cleveland, B. Kleiner, P.A. Tukey, Graphical Methods for Data Analysis, Wadworth International Group, California, 1983, pp. 60-63.

[33] R. Core Team, R: A Language and Environment for Statistical Computing, R Foundation for Statistical Computing, Vienna, Austria, 2014. URL http://www. R-project.org/.

[34] John Tukey, Exploratory Data Analysis, Addison-Wesley, 1977, pp. 43-44.

[35] Heba Z. Sailem, Julia E. Sero, Chris. Bakal, Visualizing cellular imaging data using PhenoPlot, Nat. Commun. 6 (2015) 5825. 
[36] H.V. Unadkat, N. Groen, J. Doorn, B. Fischer, A.M.C. Barradas, M. Hulsman, J. van de Peppel, L. Moroni, J.P. van Leeuwen, M.J.T. Reinders, C.A. van Blitterswijk, J. de Boer, High content imaging in the screening of biomaterial-induced MSC behavior, Biomaterials 34 (2013) 1498-1505.

[37] J. Rittscher, Characterization of biological processes through automated image analysis, Annu. Rev. Biomed. Eng. 12 (2010) 315-344.

[38] Z. Pincus, J.A. Theriot, Comparison of quantitative methods for cell-shape analysis, J. Microsc. 227 (2007) 140-156.

[39] S. Cai, H. Xu, Q. Jiang, Y. Yang, Novel 3D electrospun scaffolds with fibers oriented randomly and evenly in three dimensions to closely mimic the unique architectures of extracellular matrices in soft tissues: fabrication and mechanism study, Langmuir 29 (2013) 2311-2318.

[40] N.M. Neves, R. Campos, A. Pedro, J. Cunha, F. Macedo, R.L. Reis, Patterning of polymer nanofiber meshes by electrospinning for biomedical applications, Int. J. Nanomed. 2 (2007) 433-448.

[41] K. Zhang, X. Wang, D. Jing, Y. Yang, M. Zhu, Bionic electrospun ultrafine fibrous poly(L-lactic acid) scaffolds with a multi-scale structure, Biomed. Mater. 4 (2009) 035004.

[42] C. Jia, D. Yu, M. Lamarre, P.L. Leopold, Y.D. Teng H. Wang Patterned electrospun nanofiber matrices via localized dissolution: potential for guided tissue formation, Adv. Mater. 26 (2014) 8192-8197.

[43] T.D. Brown, P.D. Dalton, D.W. Hutmacher, Direct writing by way of melt electrospinning, Adv. Mater. 23 (2011) 5651-5657.

[44] C. Wei, J. Dong, Direct fabrication of high-resolution three-dimensional polymeric scaffolds using electrohydrodynamic hot jet plotting, J. Micromech. Microeng. 23 (2013) 025017.
[45] H. Chen, J. Huang, J. Yu, S. Liu, P. Gu, Electrospun chitosan-graft-poly ( $\varepsilon^{-}$ caprolactone)/poly ( $\varepsilon$-caprolactone) cationic nanofibrous mats as potential scaffolds for skin tissue engineering, Int. J. Biol. Macromol. 48 (2011) 13-19.

[46] S. Heydarkhan-Hagvall, K. Schenke-Layland, A.P. Dhanasopon, F. Rofail, H Smith, B.M. Wu, R. Shemin, R.E. Beygui, W. R. MacLellan, Three-dimensiona electrospun ECM-based hybrid scaffolds for cardiovascular tissue engineering, Biomaterials 29 (2008) 2907-2914.

[47] W.-J. Li, C.T. Laurencin, E.J. Caterson, R.S. Tuan, F.K. Ko, Electrospun nanofibrous structure: a novel scaffold for tissue engineering, J. Biomed Mater. Res. 60 (2002) 613-621.

[48] M. Guvendiren, J.A. Burdick, Stem cell response to spatially and temporally displayed and reversible surface topography, Adv. Healthc. Mater. 2 (2013) 155-164.

[49] A. Curtis, C. Wilkinson, Topographical control of cells, Biomaterials 18 (1997) $1573-1583$

[50] C.S. Chen, M. Mrksich, S. Huang, G.M. Whitesides, D.E. Ingber, Geometric control of cell life and death, Science 276 (1997) 1425-1428.

[51] E.K.F. Yim, E.M. Darling, K. Kulangara, F. Guilak, K.W. Leong, Nanotopographyinduced changes in focal adhesions, cytoskeletal organization, and mechanical properties of human mesenchymal stem cells, Biomaterials 31 (6) (2010) 1299.

[52] A.M. Leferink, D. Santos, M. Karperien, R.K. Truckenmüller, C.A. van Blitterswijk, L. Moroni, Differentiation capacity and maintenance of differentiated phenotypes of human mesenchymal stromal cells cultured on two distinct types of 3D polymeric scaffolds, Integr. Biol. (Camb) 7 (2015) 1574-1586. 